\title{
Single-stranded endonuclease activity in the excretory-secretory products of Trichinella spiralis and Trichinella pseudospiralis
}

\author{
C. H. MAK, Y. Y. Y. CHUNG and R. C. KO* \\ Department of Zoology, The University of Hong Kong, Pokfulam, Hong Kong, China
}

(Received 10 August 1999; revised 8 November 1999; accepted 11 December 1999)

\section{S U M M A R Y}

A novel acidic extracellular single-stranded endonuclease was demonstrated for the first time in the excretory-secretory (E-S) products of 2 species of Trichinella. Unlike the double-stranded endonuclease reported earlier, the single-stranded molecule is divalent cation independent and is detected in both T. spiralis and T. pseudospiralis $\mathrm{E}-\mathrm{S}$ products. It hydrolysed single-stranded DNA and RNA at comparable rates. The single-stranded endonuclease was sensitive to inhibition by $\mathrm{Zn}^{2+}$ and to high concentrations of $\mathrm{NaCl}$. Zymographic analysis indicated that it was encoded by at least 3 peptides of $M_{\mathrm{r}} \sim 50-60 \mathrm{kDa}$. The rate of hydrolysis of single-stranded targets by the E-S products was substantially higher than that of the double-stranded molecule. Due to the differences in peptide profile, divalent cation dependence, and species-specific expression, the single and double-stranded endonucleases are likely to be encoded by different proteins and may have different functions.

Key words: endonuclease, Trichinella spiralis, Trichinella pseudospiralis, single-stranded endonuclease, excretorysecretory products.

\section{INTRODUCTION}

Trichinella spiralis is a pathogenic nematode which parasitizes the striated muscles of mammals. The worm can reorganize the host muscles into a new syncytium known as the nurse cell complex which is circumscribed by collagenous fibres. Trichinella pseudospiralis is a closely related species which can infect both mammals and birds. However, the latter does not induce the formation of nurse cells and the site of the worm is not encapsulated. The worm can move freely along the myofibres, eliciting little inflammatory response.

In an earlier study, we detected the activity of double-stranded endonuclease in the excretorysecretory $(\mathrm{E}-\mathrm{S})$ products of the infective-stage larvae of $T$. spiralis maintained at $37^{\circ} \mathrm{C}$, but much weaker in the E-S products of $T$. pseudospiralis (Mak \& Ko, 1999). Since endonucleases have not been found previously in parasitic organisms, their functions are completely unknown.

In other microorganisms, such as Mycoplasma, endonuclease is well known to play a significant role in modulating the genomic expression of host cells or act as a potential pathogenic determinant (Bendjennat et al. 1997). In Epstein-Barr virus, it provides nucleotides for DNA synthesis, and in herpes simplex virus, it pertains a host genome-shut off

* Corresponding author. Tel: +852 2299 0835. Fax:

+852 2559 9114. E-mail: rcko@hkucc.hku.hk function (Feighny, Henry \& Pagano, 1981; Krikorian \& Read, 1991). Similar to these microorganisms, Trichinella may also possess an endonuclease that is directly or indirectly involved in the transformation of host cells (Ko \& Mak, 1999). Our discovery of endonuclease in a parasite may have broad biological implications. It now appears that during evolution, parasitic nematodes may have adopted the same strategy as viruses, bacteria and other microorganisms in the colonization of cells.

Recently, we have discovered that, besides the double-stranded endonuclease, a single-stranded molecule also occurs in the $\mathrm{E}-\mathrm{S}$ products of $T$. spiralis and T. pseudospiralis. Since the two endonucleases are distinct in their peptide profile, cation dependence and species-specific expression, it would be worthwhile to report on the characterization of the novel single-stranded endonuclease.

\section{MATERIALS AND METHODS}

\section{Trichinella $E-S$ products}

Infective-stage larvae of $T$. spiralis or $T$. pseudospiralis were isolated from muscles of experimentally infected ICR mice by the standard pepsin digestion method. After recovery, the larvae were washed twice with DMEM medium supplemented with penicillin $(100 \mathrm{U} / \mathrm{ml})$ and streptomycin $(100 \mu \mathrm{g} / \mathrm{ml})$, and counted under a stereo-microscope. E-S products from $T$. spiralis (TSES) or $T$. pseudospiralis 
(TPES) were obtained by incubating viable larvae $(10000$ larvae $/ \mathrm{ml})$ at $37^{\circ} \mathrm{C}$ for $24 \mathrm{~h}$ in DMEM medium supplemented with antibiotics and Complete proteases inhibitor (Boehringer Mannheim). Fifteen millilitres of E-S products were concentrated 100-fold by ultrafiltration using Centriplus-10 (Amicon). Protein concentrations were determined by the Bradford dye binding procedure (BioRad). Concentrated E-S products were then analysed by SDS-PAGE and visualized by Coomassie blue staining.

To inhibit the worm from producing $\mathrm{E}-\mathrm{S}$ products, freshly isolated larvae were inactivated by freezing/thawing 3 times in liquid nitrogen $/ 37^{\circ} \mathrm{C}$ water bath. The treated larvae were washed with DMEM medium and incubated as described above.

E-S products were pre-cleared by immunoprecipitation. Anti-E-S IgG antibodies were immobilized on Protein A-agarose as described (Mak \& Ko, 1999). Pre-immune serum and antiserum raised against the $T$. spiralis crude extract were used as a control. IgG-Protein A-agarose was incubated with $50 \mu \mathrm{g}$ TSES at room temperature for $1 \mathrm{~h}$. Protein A-antibody-antigen complexes were removed from the $\mathrm{E}-\mathrm{S}$ products by centrifugation. Pre-cleared $\mathrm{E}-\mathrm{S}$ products were used in the nuclease assays.

\section{Preparation of endonuclease substrates}

M13mp19(+) single-stranded circular DNA and $7 \cdot 5 \mathrm{~kb}$ poly(A)-Tailed RNA were purchased from Life Technologies. Single-stranded salmon sperm DNA was generated by boiling the native DNA for $10 \mathrm{~min}$, followed by snap-cooling on ice. Linear plasmid DNA was obtained by digesting the pBluescript SK II plasmid with restriction enzyme EcoR V.

\section{pH, monovalent and divalent cation dependence}

Standard mixtures containing $0.5 \mu \mathrm{g}$ M13 singlestranded DNA or $0.5 \mu \mathrm{g}$ poly(A) RNA were incubated for $10 \mathrm{~min}$ with $1 \mu \mathrm{g} T$. spiralis $\mathrm{E}-\mathrm{S}$ products in reaction buffer $(10 \%$ glycerol, $40 \mathrm{~mm}$ Tris$\mathrm{HCl} /$ Tris, $\mathrm{pH} 4 \cdot 0-9 \cdot 0,50 \mathrm{~mm} \mathrm{NaCl}, 1 \mathrm{~mm}$ D'T'T) supplemented with $10 \mathrm{~mm}$ EDTA. To determine the divalent cation dependence of the endonucleases, the reaction buffer at $\mathrm{pH} 6.0$ was supplemented with $2.5 \mathrm{~mm}$ different divalent cations $\left(\mathrm{Ca}^{2+}, \mathrm{Mg}^{2+}, \mathrm{Mn}^{2+}\right)$, $5 \mathrm{~mm} \mathrm{Zn}^{2+}$ ion or 2.5/10 mm EDTA at conditions as described. To determine the monovalent cation dependence, the reaction buffer at $\mathrm{pH} 6.0$ with $10 \mathrm{~mm}$ EDTA was supplemented with $\mathrm{NaCl}$ at concentrations from 10 to $500 \mathrm{~mm}$. Proteins were removed from the mixture by adding $20 \mu \mathrm{g}$ proteinase $\mathrm{K}$ and $0.5 \% \mathrm{SDS}$ and incubated for $10 \mathrm{~min}$ at $37^{\circ} \mathrm{C}$. The digested products were resolved in $1 \%$ agarose gel and visualized by staining with ethidium bromide.
Kinetics of single and double-stranded endonuclease

One microgram of linearized pBluescript SK II plasmid was incubated with $1 \mu \mathrm{g}$ TSES or TPES in reaction buffer $(10 \%$ glycerol, $40 \mathrm{~mm}$ Tris $-\mathrm{HCl}, \mathrm{pH}$ 6.0, $50 \mathrm{~mm} \mathrm{NaCl}, 1 \mathrm{~mm}$ DTT, $2.5 \mathrm{~mm} \mathrm{MnCl}_{2}$ ) at $37^{\circ} \mathrm{C}$ for $60-240 \mathrm{~min}$. Finally $0.5 \mu \mathrm{g}$ M13 singlestranded DNA or poly(A) RNA was incubated with $1 \mu \mathrm{g} \mathrm{E}-\mathrm{S}$ products in the reaction buffer supplemented with $10 \mathrm{~mm}$ EDTA at room temperature for 2.5-10 $\mathrm{min}$.

\section{Zymographic analysis of endonuclease activity}

The pattern of the endonucleases detected was examined using established procedures, with several modifications (Rosenthal \& Lacks, 1977). First, $20 \mu \mathrm{g} / \mathrm{ml}$ of denatured salmon sperm DNA, and secondly, $10 \mu \mathrm{g} / \mathrm{ml}$ bovine serum albumin were incorporated into $12 \%$ separating gels (containing $0.1 \%$ electrophoresis grade SDS) (Boehringer Mannheim). T. spiralis crude extracts, $\mathrm{E}-\mathrm{S}$ products of $T$. spiralis and T. pseudospiralis were loaded into the gels and resolved by electrophoresis at $40 \mathrm{mV}$ until the dye reached the bottom. SDS was then removed by overnight incubation at room temperature in 2 changes of $250 \mathrm{ml}$ of renaturation buffer (40 mM Tris-HCl, pH 7·0, 0.04\% 2-mercaptoethanol, $2 \mathrm{~mm}$ EDTA, $1 \%$ casein), with constant agitation. The nuclease activity of the resolved peptides was reactivated by rinsing the gel twice with distilled water, before it was transferred to $250 \mathrm{ml}$ of activation buffer $(0 \cdot 04 \mathrm{M}$ Tris $-\mathrm{HCl}, \mathrm{pH} 6 \cdot 0,50 \mathrm{~mm}$ $\mathrm{NaCl}, 1 \mathrm{~mm}$ DTT, $10 \%$ glycerol and $10 \mathrm{~mm}$ EDTA). The gel was incubated statically at room temperature for $24 \mathrm{~h}$. DNA was visualized by staining with ethidium bromide at the concentration of $2 \mu \mathrm{g} / \mathrm{ml}$ for $30 \mathrm{~min}$. Degraded DNA would not be stained by ethidium bromide and appeared as dark bands in the gel. After destaining in $250 \mathrm{ml}$ of autoclaved water for $30 \mathrm{~min}$, the pattern of nuclease activity was recorded by the Gel Doc 100 system (BioRad).

RESULTS

Nuclease activity between $E-S$ products of different species

To compare the mode of action of endonucleases between E-S products of T. spiralis and T. pseudospiralis, linear plasmid DNA, M13mp19(+) singlestranded circular DNA and $7 \cdot 5 \mathrm{~kb}$ poly(A) RNA were incubated with various $\mathrm{E}-\mathrm{S}$ products and the digested products were resolved in $1 \%$ agarose gel. Activities of both single-stranded and doublestranded endonucleases were detected in Trichinella E-S products. Within $10 \mathrm{~min}, \mathrm{E}-\mathrm{S}$ products from $T$. spiralis (TSES) and T. pseudospiralis (TPES) com- 
$\mathbf{A}$

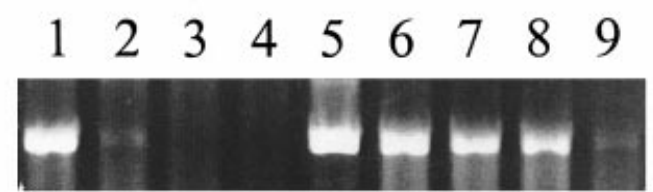

B

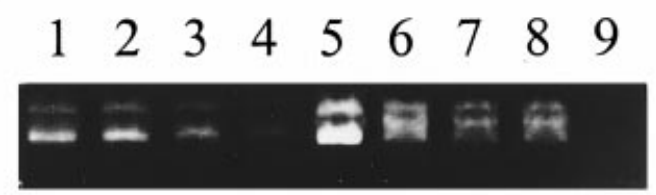

C

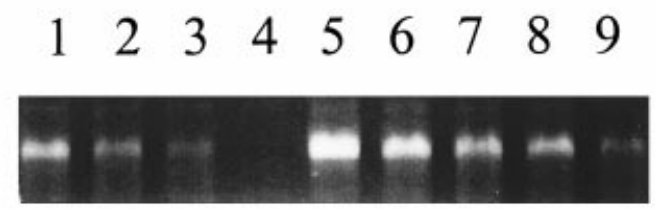

Fig. 1. Rate of hydrolysis of dsDNA, ssDNA and RNA by TSES and TPES. Double-stranded (ds) DNA was incubated with $1 \mu \mathrm{g}$ E-S products in $\mathrm{pH} 6.0$ reaction buffer supplemented with $2.5 \mathrm{mM} \mathrm{Mn}^{2+}$ ion at $37^{\circ} \mathrm{C}$ for 60-240 min. Single-stranded (ss) DNA and RNA were incubated with the $\mathrm{E}-\mathrm{S}$ products in $\mathrm{pH} 6.0$ buffer containing $10 \mathrm{~mm}$ EDTA for $2 \cdot 5-10 \mathrm{~min}$. (A) $1 \mu \mathrm{g}$ dsDNA was incubated with $1 \mu \mathrm{g}$ TSES (lanes 1-4) and TPES (lanes 6-9) for various time periods; lane 5 : substrate alone; lanes 1 and $6: 60 \mathrm{~min}$, lanes 2 and 7: $120 \mathrm{~min}$, lanes 3 and $8: 180 \mathrm{~min}$, lanes 4 and 9: $240 \mathrm{~min}$. (B) $0.5 \mu \mathrm{g}$ ssDNA and (C) RNA were incubated with TSES (lanes 1-4) and TPES (lanes 6-9) for various time periods; lane 5 : substrate alone; lanes 1 and $6: 2.5 \mathrm{~min}$, lanes 2 and $7: 5 \mathrm{~min}$, lanes 3 and 8 : $7 \cdot 5 \mathrm{~min}$ and lanes 4 and 9: $10 \mathrm{~min}$. The digested products were analysed in $1 \%$ agarose gel, and stained with ethidium bromide.

pletely degraded the single-stranded DNA and RNA (Fig. 1 B, C). The rate of hydrolysis of the singlestranded DNA and RNA was comparable in the 2 E-S products. However, only TSES degraded linearized plasmid after $120 \mathrm{~min}$ incubation. Similar incubations of TPES with dsDNA did not degrade a significant amount of DNA (Fig. 1A). A substantially weaker double-stranded endonuclease activity was expressed in TPES. As compared to the native dsDNA, all E-S products attacked the singlestranded polynucleotides at a markedly higher rate, indicating the substrate preference of the endonuclease for single-stranded DNA and RNA.

\section{Biochemical properties of endonuclease activity}

TSES single-stranded endonuclease activity was divalent cation independent, and fully active in the
A

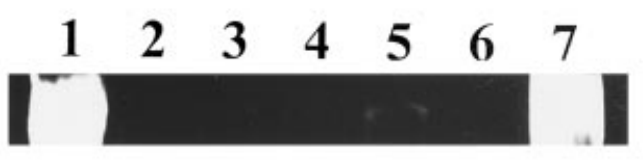

B

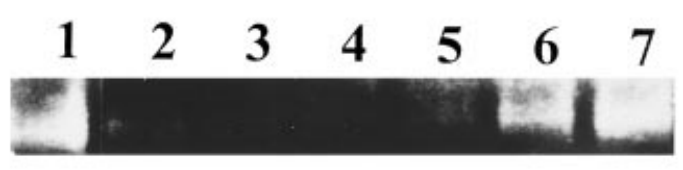

C

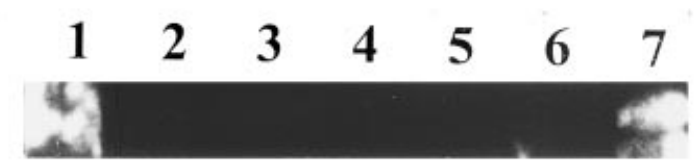

Fig. 2. Effect of cation, $\mathrm{pH}$ and ionic strength on the nuclease activity. Samples of $0.5 \mu \mathrm{g}$ circular singlestranded DNA were incubated with $1 \mu \mathrm{g}$ Trichinella spiralis $\mathrm{E}-\mathrm{S}$ products in various reaction buffers for $10 \mathrm{~min}$. (A) Effect of divalent cations. The experiment was performed in $\mathrm{pH} 6.0$ buffer containing $50 \mathrm{~mm} \mathrm{NaCl}$. Lane 1, substrate alone; lanes 2-7; $2.5 \mathrm{~mm}$ EDTA, $10 \mathrm{~mm}$ EDTA, $2.5 \mathrm{~mm} \mathrm{Ca}^{2+}, 2.5 \mathrm{~mm} \mathrm{Mg}^{2+}, 2 \cdot 5 \mathrm{~mm} \mathrm{Mn}^{2+}$ and $5 \mathrm{~mm} \mathrm{Zn}^{2+}$, respectively. (B) Effect of $\mathrm{pH}$. The experiment was performed in buffer containing $50 \mathrm{~mm}$ $\mathrm{NaCl}$ and $10 \mathrm{~mm}$ EDTA. Lane 1: substrate alone; lanes 2-7: pH 4, 5, 6, 7, 8 and 9, respectively. (C) Effect of ionic strength. The experiment was performed in $\mathrm{pH} 6$ buffer supplemented with $10 \mathrm{~mm}$ EDTA. Lane 1: substrate alone; lanes 2-7: 10, 25, 50, 100, 250, $500 \mathrm{~mm}$ $\mathrm{NaCl}$, respectively. Reaction products were separated by electrophoresis in $1 \%$ agarose gel, and visualized by ethidium bromide staining.

presence of $10 \mathrm{~mm}$ EDTA. Replacing the divalent cations with $5 \mathrm{~mm} \mathrm{Zn}^{2+}$ completely abolished the nuclease activity (Fig. 2A). The optimal $\mathrm{pH}$ for single-stranded endonucleases was acidic (Fig. $2 \mathrm{~B}$ ). It was most active at $\mathrm{pH}$ below 8. Enzymatic activities of the single-stranded endonucleases were optimal in low ionic strength buffer. At $500 \mathrm{~mm}$ $\mathrm{NaCl}$, the nuclease activities were inhibited (Fig. $2 \mathrm{C})$. Similar results were obtained when $T$. pseudospiralis $\mathrm{E}-\mathrm{S}$ products or $7.5 \mathrm{~kb}$ poly(A) RNA was used (data not shown).

\section{Authenticity of nuclease activity in $E-S$ products}

The main purpose of freezing/thawing and immunoprecipitation experiments was to determine whether the detected endonuclease is a real $\mathrm{E}-\mathrm{S}$ component or a leaky byproduct of the larval somatic enzymes. Examination under a microscope showed that after 
A

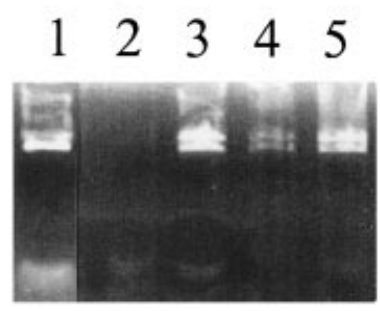

B

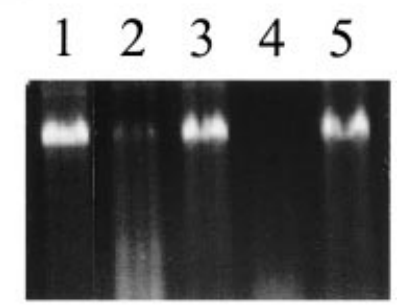

Fig. 3. Freezing/thawing of worms inactivates endonuclease activity. Trichinella spiralis and T. pseudospiralis secretory products were incubated with $0.5 \mu \mathrm{g}$ ssDNA (A) or $0.5 \mu \mathrm{g}$ RNA (B) in $\mathrm{pH} 6.0$ reaction buffer containing $10 \mathrm{~mm}$ EDTA. Digested products were resolved by $1 \%$ agarose gel, and stained with ethidium bromide. Lane 1 : control (incubated without E-S products); lane 2: $1 \mu \mathrm{g}$ TSES; lane 3: 0.3 $\mu \mathrm{g}$ TSES-Freeze; lane 4: $1 \mu \mathrm{g}$ TPES; lane 5: $0 \cdot 3 \mu \mathrm{g}$ TPES-Freeze.

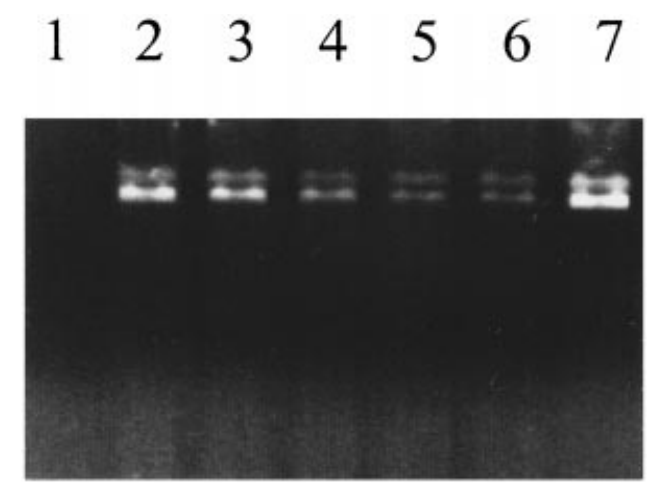

Fig. 4. Neutralization of TSES endonuclease activity by anti-E-S serum. Endonuclease neutralizing activities of various sera on single-stranded endonuclease were tested by immunoprecipitating TSES with various antibodies. The pre-cleared extracts were used in nuclease assays with single-stranded DNA as substrates. The digested products were resolved in $1 \%$ agarose gel, and stained with ethidium bromide. Lane 1: TSES without treatment; lane 2: TSES immunoprecipitated with antiTSES antibodies; lane 3: TSES immunoprecipitated with anti-TPES antibodies; lane 4: TSES immunoprecipitated with anti-Trichinella spiralis crude extract antibodies; lane 5: TSES immunoprecipitated with normal rabbit antibodies; lane 6: TSES immunoprecipitated with Protein A-agarose; lane 7 : control (substrate alone).

freezing and thawing, more than $90 \%$ of the worms were killed. The concentration of the $\mathrm{E}-\mathrm{S}$ products produced by the treated larvae was only about $25 \%$ of the untreated sample (data not shown). Fig. 3 shows that after treatment, single-stranded endonuclease activity was abolished. Endonuclease activities were only observed in the untreated samples. Authenticity of the endonuclease was further analysed by immunoprecipitation using antibodies raised against the Trichinella $\mathrm{E}-\mathrm{S}$ products. TSES single-stranded endonuclease was recognized by $\mathrm{IgG}$ from both anti-TSES and anti-TPES sera but not by normal or antiserum against $T$. spiralis crude somatic worm extracts (TSCE) (Fig. 4). After immunoprecipitation with the respective antiserum, most single-stranded endonuclease activities were abolished. The slight decrease in enzymatic activity observed in the immunoprecipitation process (Fig. 4, lanes 4-6) was probably due to the non-specific binding of the $\mathrm{E}-\mathrm{S}$ products to Protein $\mathrm{A}$-agarose. However, the decrease was insignificant as compared to those of the experimental samples. The data indicate that the single-stranded endonucleases of both T. spiralis and T. pseudospiralis are authentic components of the larval $\mathrm{E}-\mathrm{S}$ products. They may be encoded by similar proteins, or they share a common epitope.

\section{Zymographic analysis of endonucleases}

The patterns of renaturable endonuclease activities of TSES, TPES and TSCE were analysed in polyacrylamide gels containing heat-denatured salmon sperm DNA. The integrity and concentration of the samples were determined by SDSPAGE and Coomassie blue staining (Fig. 5A). Single-stranded endonuclease activities were terminated after $24 \mathrm{~h}$ of incubation. In situ hydrolysis of the target DNA results in a reduction in ethidium bromide fluorescence.

Using heat-denatured salmon sperm DNA as substrate, comparable single-stranded endonuclease activity was detected in TSES and TPES. A much weaker activity was detected in TSCE, which may have originated from residual $\mathrm{E}-\mathrm{S}$ products expressed in the larvae. Three prominent bands, with apparent molecular masses of $\sim 50-60 \mathrm{kDa}$, were observed to be associated with the single-stranded endonuclease activity in TSES and TPES (Fig. 5 B).

\section{DISCUSSION}

Little is known about endonucleases in parasitic organisms. Following our previous discovery of a specific, double-stranded endonuclease of T. spiralis (Mak \& Ko, 1999), the present study documents a second non-specific, and faster action singlestranded molecule in the $\mathrm{E}-\mathrm{S}$ products of $T$. spiralis 


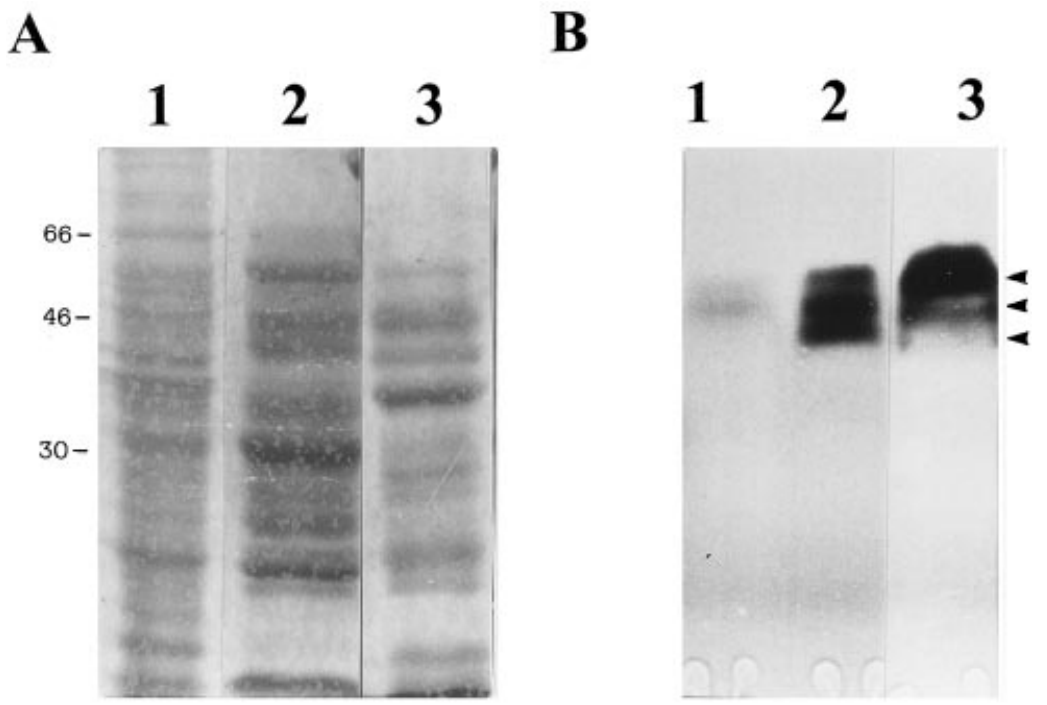

Fig. 5. SDS-PAGE nuclease band pattern of the endonuclease activity of various worm extracts. Samples of $40 \mu \mathrm{g}$ of Trichinella spiralis crude extract (lane 1), TPES (lane 2), and TSES (lane 3) were subjected to electrophoresis in $12 \%$ SDS-polyacrylamide gel (A) or polyacrylamide gel containing $10 \mu \mathrm{g} / \mathrm{ml}$ bovine serum albumin and $20 \mu \mathrm{g} / \mathrm{ml}$ heatdenatured salmon sperm DNA (B). After electrophoresis, gel was stained with Coomassie blue (A), or the nuclease activity in the gel was reactivated (B). Nuclease activity was identified by staining the remaining DNA with ethidium bromide and visualized by UV illumination. Degraded DNA which would not be stained appeared as dark bands. $M_{\mathrm{r}}$ markers are indicated on the left side. Arrows indicate the positions of the major endonuclease activities.

and T. pseudospiralis. The finding of 2 types of endonucleases in Trichinella indicates that the parasite-induced changes in host muscle cells may involve complicated pathways.

As in other eukaryotes, non-long terminal repeat retrotransposons are widespread in genomes of parasitic worms like Schistosoma mansoni and Caenorhabditis elegans (Bowen \& McDonald, 1999; Drew et al. 1999). The retrotransposable element encodes an endonuclease that is crucial to the integration process (Yang, Malik \& Eickbush, 1999). Since retrotransposition occurs in the nucleus, the endonuclease has been suggested to be basically an intracellular enzyme. However, the endonuclease observed in Trichinella is likely to be extracellular. It was detected in substantial quantity only in the E-S products. Freezing/thawing larvae (to break the cells) failed to increase the level of activity. The activity could also be blocked by antiserum against $\mathrm{E}-\mathrm{S}$ products. Therefore, we believe that the endonuclease is an authentic component of the larval E-S products.

The biochemical properties of the novel singlestranded endonuclease of Trichinella differ from those of other well-characterized molecules. This is the first report of an extracellular acidic singlestranded endonuclease whose activity is independent of divalent cations. Most well-known singlestranded endonucleases such as those from KB cells (a continuous line of human epithelial cell), aneuploid cells, and mouse plasmacytoma mitochondria are divalent cation dependent (Pedrini et al. 1976; Wang \& Rose, 1981; Kouidou et al. 1987). Nucleases secreted by Streptococcal strain S43, Staphylococcus aureus, basidiomycete fungus Armillaria mellea, and Rhizopus stolonifer require divalent cations as a cofactor (Citak \& Gray, 1980; Udou \& Ichik'awa, 1980; Chacko \& Shankar, 1998; Healy, Doonan \& McCarthy, 1999). Activities of other well-characterized extracellular nucleases such as Serratia marcescens nuclease, Cunninghamella echinulata var. echinulata nuclease $\mathrm{C} 1$ and barley nuclease are inhibited by EDTA (Brown \& Ho, 1987; Benedik \& Strych, 1998; Ho et al. 1998). Endonucleases with similar properties are secreted by Dictyostelium discoideum, Aspergillus, Bacillus subtilis and Vibrio (Maeda \& Taga, 1976; Guyer, Skantar \& Deering, 1985 ; Kafer, Tittler \& Fraser, 1989; Nakamura et al. 1992). The molecular masses of nucleases produced by $S$. marcescens, C. echinulata, barley, B. subtilis, D. discoideum, Aspergillus and Vibrio are 30.6, 30, 35, $32,44,88$ and $100 \mathrm{kDa}$, respectively. These are quite distinctive from those of the endonuclease detected in the present study.

Significant differences (especially in their peptide profile, cation dependence, and species-specific expression) occur between the single and doublestranded endonuclease of Trichinella. The doublestranded endonuclease is divalent cation dependent and is encoded by peptides with $M_{\mathrm{r}} \sim 25,30$ and $58 \mathrm{kDa}$. It is mainly expressed in T. spiralis $\mathrm{E}-\mathrm{S}$ products (Mak \& Ko, 1999). On the other hand, the single-stranded endonuclease is divalent cation independent, encoded by peptides with $M_{\mathrm{r}} \sim 50$ $60 \mathrm{kDa}$. It is expressed in both $T$. spiralis and $T$. pseudospiralis. Therefore, the two endonucleases are probably encoded by different $\mathrm{E}-\mathrm{S}$ proteins and may play a distinct role in the reorganization of host 
tissues or in pathogenesis. However, the expression pattern of the single-stranded endonuclease suggests that it may have a more general role.

In viruses, endonucleases are associated with replication/integration. Single-stranded endonucleases are also involved in restriction of foreign DNA, homologous recombination, RNA editing and DNA repairing (Maeda \& Taga, 1976; Pham \& Coleman, 1985 ; Panet \& Baltimore, 1987; Trujillo et al. 1998). In Mycoplasma penetrans, it degrades host nucleic acids to acquire the precursors for nucleic acid biosynthesis, leading to chromosomal alterations (Bendjennat et al. 1997). In E. coli, RNase III can affect genomic expression by influencing posttranscriptional control of mRNA stability, or mRNA translational efficiency (Dasgupta et al. 1998). Many pathogen-associated endonucleases, e.g. the virion host shutoff protein, and some viral nucleases, can degrade the host mRNA selectively, and stop the metabolism of the host cell (Krikorian \& Read, 1991). Also, the $20 \mathrm{~S}$ proteasome with intrinsic endonuclease activity can alter the turnover of cellular proteins by regulating the post-transcriptional gene expression (Petit et al. 1997). As in the above microorganisms, the single-stranded endonuclease of Trichinella may also be involved in a variety of functions but further studies are required to substantiate this hypothesis.

The work was supported by a grant (HKU 426/96M) from the Hong Kong Research Grants Council to R. C. K. and a partial postdoctorate fellowship from the University of Hong Kong to C.H.M.

\section{REFERENCES}

BENDJENNAT, M., BLANCHARD, A., LOUTFi, M., MONTAgnier, L. \& Bahraoui, E. (1997). Purification and characterization of Mycoplasma penetrans $\mathrm{Ca}^{2+} / \mathrm{Mg}^{2+}$-dependent endonuclease. Fournal of Bacteriology 179, 2210-2220.

BENEDIK, M. J. \& STRYCH, U. (1998). Serratia marcescens and its extracellular nuclease. FEMS Microbiology Letter 165, 1-13.

BOWEN, N. J. \& McDONALD, J. F. (1999). Genomic analysis of Caenorhabditis elegans reveals ancient families of retroviral-like elements. Genome Research 9, 924-935.

BROWN, P.H. \& HO, T. H. (1987). Biochemical properties and hormonal regulation of barley nuclease. European Journal of Biochemistry 168, 357-364.

CHACKO, R. \& SHANKAR, v. (1998). Extracellular ribonuclease from Rhizopus stolonifer: characteristics of a typical-guanylic acid preferential-enzyme from ribonuclease T2 family. Biochimica et Biophysica Acta 1379, 264-272.

CITAK, B. P. \& GRAY, E. D. (1980). Isolation and characterization of cell-associated nucleases related to streptococcal extracellular deoxyribonuclease D.

Fournal of Bacteriology 141, 584-592.

DASGUPTA, S., FERNANDEZ, L., KAMEYAMA, L., INADA, T., NAKAMURA, Y., PAPPAS, A. \& COURT, D. L. (1998).
Genetic uncoupling of the dsRNA-binding and RNA cleavage activities of the Escherichia coli endoribonuclease RNase III - the effect of dsRNA binding on gene expression. Molecular Microbiology 28, 629-640.

DREW, A. C., Minchella, D. J., King, L. T., ROllinson, D. \& BRINDLEY, P. J. (1999). SR2 elements, non-long terminal repeat retrotransposons of the RTE-1 lineage from the human blood fluke Schistosoma mansoni. Molecular Biology and Evolution 16, 1256-1269.

FEIGHNY, R. J., HENRY, B. E. II \& PAGANO, J. S. (1981). Epstein-Barr virus-induced deoxynuclease and reutilization of host-cell DNA degradation products in viral DNA replication. Virology 115, 395-400.

GUYER, R. B., SKANTAR, A. M. \& DEERING, R. A. (1985). Acid DNase activity from Dictyostelium discoideum. Biochimica et Biophysica Acta 826, 151-153.

HEALy, v., DOONAN, S. \& MCCARTHY, T. v. (1999).

Purification, characterization and cDNA cloning of an endo-exonuclease from the basidiomycete fungus Armillaria mellea. The Biochemical Fournal 339, 713-720.

HO, H. C., ShiaU, P. F., LiU, F. C., ChUnG, J. G. \& CHen, L. Y. (1998). Purification, characterization and complete amino acid sequence of nuclease $\mathrm{C} 1$ from Cunninghamella echinulata var. echinulata. European Fournal of Biochemistry 256, 112-118.

KAFER, E., TitTler, A. \& FRASER, M. J. (1989). A single, phosphate-repressible deoxyribonuclease, DNase A, secreted in Aspergillus nidulans. Biochemical Genetics 27, 153-166.

KO, R. C. \& MAK, C. H. (1999). Trichinellosis as a model of new frontier research on parasitic infection.

International Medical Research Fournal 3, 1-11.

Kouidou, s. A., TRIANTOS, A. A., PAPAgEORgioU, G. E., KaVOUKOPOUlos, E. M., VAVATSI, N. A. \& TRAKATELlis, A. C. (1987). Single-strand-specific nuclease from rat liver endoplasmic reticulum: characterization and mode of action. International Fournal for Biochemistry 19, 857-864.

KRIKORIAN, C. R. \& READ, G. S. (1991). In vitro mRNA degradation system to study the virion host shutoff function of herpes simplex virus. Fournal of Virology 65, 112-122.

MAEDA, M. \& TAGA, N. (1976). Extracellular nuclease produced by a marine bacterium. II. Purification and properties of extracellular nuclease from a marine Vibrio sp. Canadian Fournal of Microbiology 22, 1443-1452.

MAK, C. H. \& KO, R. C. (1999). Characterization of endonuclease activity from excretory/secretory products of a parasitic nematode, Trichinella spiralis. European Fournal of Biochemistry 260, 477-481.

NAKAMURA, A., KOIDE, Y., MIYAZAKI, H., KITAMURA, A., MASAKI, H., BEPPU, T. \& UOZUMI, T. (1992). Gene cloning and characterization of a novel extracellular ribonuclease of Bacillus subtilis. European Fournal of Biochemistry 209, 121-127.

PANET, A. \& BALTimore, D. (1987). Characterization of endonuclease activities in Moloney murine leukemia virus and its replication-defective mutants. Fournal of Virology 61, 1756-1760.

PEDRINI, A. M., RANZANi, G., PEDRALI-NOY, G. C., SPADARI, 
S. \& FALASCHI, A. (1976). A novel endonuclease of human cells specific for single-stranded DNA.

European Fournal of Biochemistry 70, 275-283.

PETit, F., JARrousse, A. S., Boissonnet, G., DADET, M. H., BURI, J., BRIAND, Y. \& SCHMID, H. P. (1997).

Proteasome (prosome) associated endonuclease activity. Molecular Biology Reports 24, 113-117.

PHAM, T. T. \& COLEMAN, J. E. (1985). Cloning, expression, and purification of gene 3 endonuclease from bacteriophage T7. Biochemistry 24, 5672-5677.

Rosenthal, A. L. \& LACKS, S. A. (1977). Nuclease activity detection in polyacrylamide gels. Analytical Biochemistry 80, 76-90.

TRUjILlo, K. M., YUAN, S. S., LEE, E. Y. \& SUNG, P. (1998). Nuclease activities in a complex of human recombination and DNA repair factors Rad50, Mre11, p95. Fournal of Biological Chemistry 273, 21447-21450.

UdOU, T. \& ICHIK'AWA, Y. (1980). Effect of sodium chloride on the activity and production of Staphylococcal exonuclease. Fournal of General Microbiology 116, 69-74.

WANG, E. C. \& ROSE, J. A. (1981). Deoxyribonucleic acid single-strand-specific endonucleases in human cells: partial purification of a salt-resistant endonuclease with an acidic isoelectric point. Biochemistry 20, $755-758$.

YANG, J., MALIK, H. S. \& EICKBUSH, T. H. (1999). Identification of the endonuclease domain encoded by R2 and other site-specific, non-long terminal repeat retrotransposable elements. Proceedings of the National Academy of the Sciences, USA 96, 7847-7852. 